Our Nature (2009) 7:48-55

\title{
An Evaluation of the Pigment Composition of Eighteen Marine Macroalgae Collected from Okha Coast, Gulf of Kutch, India
}

\author{
N. Kumar J.I. ${ }^{*}$, R.N. Kumar ${ }^{2}$, A. Bora ${ }^{1}$, M. Kaur Amb ${ }^{1}$ and S. Chakraborthy ${ }^{1}$ \\ ${ }^{1}$ P.G. Department of Environmental Science and Technology, Institute of Science and Technology for Advanced \\ studies and Research (ISTAR), Vallabh Vidyanagar-388120, Anand, Gujarat, India \\ ${ }^{2}$ Department of Biological and Environmental Sciences, Natubhai V. Patel college of Pure and Applied Sciences \\ (NVPAS), Vallabh Vidyanagar-388120, Anand, Gujarat, India \\ *E-mail: istares2005@yahoo.com
}

Received: 09.04.2009, Accepted: 23.08.2009

\begin{abstract}
Marine algae are one of the most important marine living resources for food, feed and medicine since ancient times in the West. However, due to lack of awareness among the people especially in India, their multifunctional properties have not yet been exploited. This paper deals with the pigment composition and its significant variation found in eighteen different species of marine macroalgae belonging to Chlorophyta, Phaeophyta and Rhodophyta, collected from the coast of Okha, Gulf of Kutch, Gujarat, India. Chlorophyll and carotenoids extraction was done with $80 \%$ acetone as solvent while phycoerythrin pigment was extracted using $50 \mathrm{mM}$ phosphate buffer $(\mathrm{pH} 7.0)$. The highest chlorophyll content was registered in Cladophora fascicularis while carotenoid content was found to be the highest in Sargassum polycustum. Similarly phycoerythrin content was recorded greater in Scinaia farcellata followed by Porphyra necnamessis and Acanthophora delilei Lamour respectively. In terms of chlorophyll content, the maximum chlorophyll $a, b$ as well as total chlorophyll was registered in most of the species of Chlorophyta followed by Phaeophyta and ultimately Rhodophyta. However, carotenoids were registered to be the highest in most of the species of Phaeophyta group. The group wise distribution of carotenoid showed an order: Phaeophyta $>$ Rhodophyta $>$ Chlorophyta. Chl $b / \mathrm{Chl} a$, Car/Chl $a$ and Car/Chl $b$ ratios were also calculated and high ratios were recorded in Liagora erecta, S.polycustum and Padina gymnospora, respectively. Besides, phycoerythrin content showed the following trend in the species of: Rhodophyta>Phaeophyta>Chlorophyta. Emphas is was made to know the variation of different pigments of all eighteen species of marine macroalgae in this paper.
\end{abstract}

Key words: Marine macroalgae, Chlorophyll $a, b$, Carotenoid, Phycoerythrin.

\section{Introduction}

In marine ecosystem, marine algae are ecologically and biologically important as they provide nutrition, reproduction and an accommodation to other living organisms (Mc Clanahan et al., 2002; Wilson, 2002). Marine algae are macroscopic algae found 
attached to the bottom in relatively shallow coastal waters. They grow in the intertidal, shallow and deep sea areas up to 180 meters depth and also in estuaries and back waters on the solid substrates such as rocks, deep corals, pebbles, shells and other plant materials. They form one of the important living resources and are grouped under three divisions namely, Chlorophyceae, Phaeophyceae and Rhodophyceae. They are abundant on hard substrates and commonly extend to depths of 30-40 m (Kannan and Thangaradjou, 1998; Anantharaman, 2002). Lewin (1974) stated that the lipids of algae comprise photosynthetic pigmentschlorophylls and carotenes and other compounds while carotenoids are powerful antioxidants.

There are three distinct classes of pigments in marine algae generally occurring in bound and non-bound forms in the cells. Chlorophylls are greenish pigments which contain a porphyrin ring around which electrons are free to migrate. Because the electrons transfer freely, the porphyrin ring has the potential to gain or lose electrons easily, and thus the potential to provide energized electrons to other molecules. This is the fundamental process by which chlorophyll captures the energy of sunlight. On the other hand, carotenoids are usually red, orange, or yellow pigments, do not dissolve in water and must be attached to membranes within the cell. Carotenoids cannot transfer sunlight energy directly to the photosynthetic pathway, but pass their absorbed energy from one chlorophyll molecule to another. For this reason, they are called accessory pigments. Besides, phycobilins are water-soluble pigments, and are therefore found in the cytoplasm, or in the stroma of the chloroplast. They occur only in Myxophyceae and Rhodophyta. Phycobilins when exposed to strong light absorb the light energy and release it by emitting light of a very narrow range of wavelengths. The light produced by this fluorescence is so distinctive and reliable, that phycobilins may be used as chemical "tags"(UC, 2009).

Chlorophyll distribution, phytoplankton biomass and pigment diversity were investigated at fortnightly intervals in IleIfe, Nigeria (Ekpenyong, 2000). Dere et al. (2003) carried out the determination of Chlorophyll $a$ (Chl $a$ ), Chlorophyll $b$ (Chl $b$ ), Chlorophyll $c(\mathrm{Chl} c)$, total carotenoid (Car) content and $\mathrm{Chl} b / \mathrm{Chl} a$, Chl $c / \mathrm{Chl} a$, $\mathrm{Car} / \mathrm{Chl} a$, Car/Chl $a$, Car/Chl $b$ and Car/Chl $c$ ratios. Pigment contents varied significantly with respect to the algal taxa, stations and depth distribution, collected from Gemlik-Karacaali (Bursa) and ErdekOrmanli (Balikesir) in the Sea of Marmara, Turkey. Thakur et al. (2008) studied the seasonal variation in biomass and species composition of sea-weeds stranded along Port Okha, northwest coast of India. Chakraborty and Santra (2008) studied the biochemical composition of eight benthic algae collected from Sunderban and compared for their biochemical composition and stated that pigments chlorophyll $a$, chlorophyll $b$ and carotenoids were present in considerable quantities. 
Looking into the significance of marine algae, the current study is focussed on the evaluation of the pigment composition in eighteen species of marine algae belonging to three different groups from the coast of Okha, Gulf of Kutch, India.

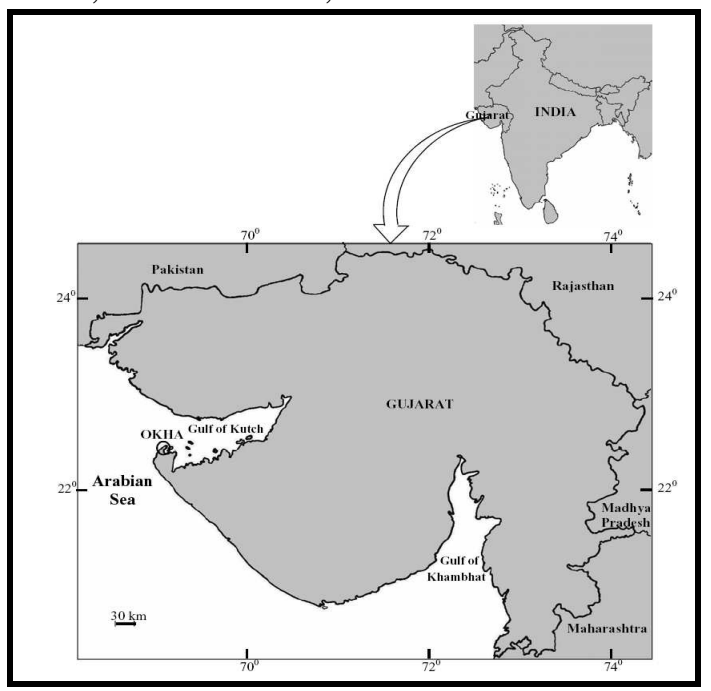

Figure 1. Map of India showing the study site of Okha, Gujarat (Thakur et al., 2008).

\section{Study area}

Coast Okha $\left(22^{\circ} 28^{\prime} \mathrm{N}\right.$ and $\left.69^{\circ} 05^{\prime} \mathrm{E}\right)$, situated at the mouth of "Gulf of Kutch" on the north- westernmost part of Saurashtra in Gujarat (Figure 1) is one of the most important places of interest for algal growth in India. This coast being at the mouth of "Gulf of Kutch" experiences strong water currents round the year as compared to other parts of the country. The coast is characterized by rocks made up of tertiary formations alternating with patches of sand deposits making the area more hospitable for the growth of all types of marine algae throughout the year. Exposure of 0.7 to 0.9 $\mathrm{km}$ width of intertidal zone for 3 to 4 hours with tidal amplitude of 4 to $5 \mathrm{~m}$ creates a unique habitat for the luxuriant growth of diverse marine algae (Thakur et al., 2008).

\section{Materials and methods \\ Sample collection}

Eighteen species of marine macroalgae (Table 1) were handpicked from substratum like mud and concrete surface from Okha coast, Gulf of Kutch during the fourth week of February, 2009. The samples were washed thoroughly to remove adhering soil particles and immediately transferred to the laboratory in ice box for analysis of various pigments.

Table 1. Different species of marine algae and their classification

\begin{tabular}{ll}
\hline Group & Name of the species \\
\hline Chlorophyta & Caulerpa racemosa \\
& C. seertulariodes \\
& Chaetomorpha. spp. \\
& Cladophora fascicularis \\
& Ulva lactuca Linn. \\
& Valoniopsis pachynema \\
& (martens) Boergs \\
\hline Phaeophyta & Dictyota bartayresiana \\
& Fucus. spp. \\
& Padina gymnospora \\
& Sargassum ilicifolium \\
& S. Polycustum \\
\hline Rhodophyta & Acanthophora delilei Lamour \\
& Champia compressa \\
& Liagora erecta \\
& Porphyra necnamessis \\
& Porphyra. spp. \\
& Scinaia farcellata \\
& Soliera robusta \\
\hline
\end{tabular}




\section{Pigment extraction}

The marine algae were estimated for different pigment content such as chlorophyll $a, b$, total chlorophyll, carotenoids and phycoerythrin content. Pigment extraction was done using $0.1 \mathrm{gm}$ fresh weight $(\mathrm{FW})$ of the marine algae for the estimation of chlorophyll $a, b$ using coefficient given by Jeffrey and Humphrey (1975) while carotenoids were estimated according to the protocol prescribed by Parsons and Strickland (1963) and both the pigments were extracted using $80 \%$ acetone by addition of pinch of magnesium carbonate $\left(\mathrm{MgCO}_{3}\right)$. Estimation of phycoerythrin (PE) pigments was done using the method given by Bennett and Bogorad (1973).

\section{Results and discussion}

Chlorophyll and carotenoid content have been represented in Figures 2 and 3.The chlorophyll $a$ content in Chlorophyta varied from 0.72 to $4.98 \mathrm{mg} \mathrm{g}^{-1} \mathrm{FW}$ while chlorophyll $a$ in Phaeophyta exhibited a range from 0.96 to $2.01 \mathrm{mg} \mathrm{g}^{-1} \mathrm{FW}$. In Rhodophyta, chlorophyll $a$ fluctuated from 0.58 to1.96 $\mathrm{mg} \mathrm{g}^{-1} \mathrm{FW}$. The highest chlorophyll a content was observed in Cladophora fascicularis $\left(6.91 \mathrm{mg} \mathrm{g}^{-1} \mathrm{FW}\right)$ followed by Caulerpa seertulariodes (4.98 $\mathrm{mg} \mathrm{g}^{-1} \mathrm{FW}$ ) while the lowest chlorophyll $a$ content was recorded in Champia compressa $\left(0.58 \mathrm{mg} \mathrm{g}^{-1} \mathrm{FW}\right)$. Amongst all the species of the three algal groups, the order of chlorophyll $a$ content is as follows: Chlorophyta $>$ Phaeophyta $>$ Rhodophyta. The results of the current study corroborated with the findings of Francisco et al. (2006) stating highest chlorophyll $a$ content in green algae and lowest in red algae.

Chl $b$ was observed to be the richest in C. fascicularis $\left(1.14 \mathrm{mg} \mathrm{g}^{-1} \mathrm{FW}\right)$ followed by Scinaia farcellata $\left(0.63 \mathrm{mg} \mathrm{g}^{-1} \mathrm{FW}\right)$. The lowest chlorophyll $b$ was noted in Sargassum polycustum $\left(0.10 \mathrm{mg} \mathrm{g}^{-1} \mathrm{FW}\right)$. The Chlorophyll $b$ values ranged from 0.2 to $1.14 \mathrm{mg} \mathrm{g}^{-1} \mathrm{FW}, 0.10$ to $0.46 \mathrm{mg} \mathrm{g}^{-1} \mathrm{FW}$ and 0.23 to $0.63 \mathrm{mg} \mathrm{g}^{-1} \mathrm{FW}$ in members of Chlorophyceae, Phaeophyceae, and Rhodophyceae respectively. Similar observations were incurred by Chakraborty and Santra (2008).The highest total chlorophyll was also registered in $C$. fascicularis $\left(8.05 \mathrm{mg} \mathrm{g}^{-1} \mathrm{FW}\right)$ followed by C. seertulariodes $\left(5.61 \mathrm{mg} \mathrm{g}^{-1} \mathrm{FW}\right)$. Meagre total chlorophyll was recorded in $C$. compressa $\left(0.82 \mathrm{mg} \mathrm{g}^{-1} \mathrm{FW}\right)$. The order of the total chlorophyll content, for all species of algal groups is as follows: Chlorophyta $>$ Phaeophyta $>$ Rhodophyta.

The ratios of $\mathrm{Chl} b / \mathrm{Chl} a, \mathrm{Car} / \mathrm{Chl} b$ and $\mathrm{Car} / \mathrm{Chl} a$ pigments of different marine algae have been represented in Table 2. Chl $b / \mathrm{Chl} a$ ratio was recorded to be the highest in Liagora erecta (0.44 $\left.\mathrm{mg} \mathrm{g}^{-1} \mathrm{FW}\right)$ followed by $C$. compressa $\left(0.41 \mathrm{mg} \mathrm{g}^{-1}\right.$ FW). The least $\mathrm{Chl} b / \mathrm{Chl} a$ ratio was observed in Fucus spp (0.07 $\left.\mathrm{mg} \mathrm{g}^{-1} \mathrm{FW}\right)$. Taking into consideration each group, the Chl $b /$ Chl $a$ values in Chlorophyta fluctuated from 0.12 to $0.28 \mathrm{mg} \mathrm{g}^{-1} \mathrm{FW}$, while the ratio in Phaeophyta varied from 0.07 to $0.30 \mathrm{mg} \mathrm{g}^{-1} \mathrm{FW}$. Similarly, in Rhodophyta, the ratio fluctuated from 0.17 to $0.44 \mathrm{mg} \mathrm{g}^{-1} \mathrm{FW}$. Chl $b / \mathrm{Chl} a$ ratio present 
N. Kumar J.I., R.N. Kumar, A. Bora, M. Kaur Amb and S. Chakraborthy / Our Nature

(2009) 7: 48-55

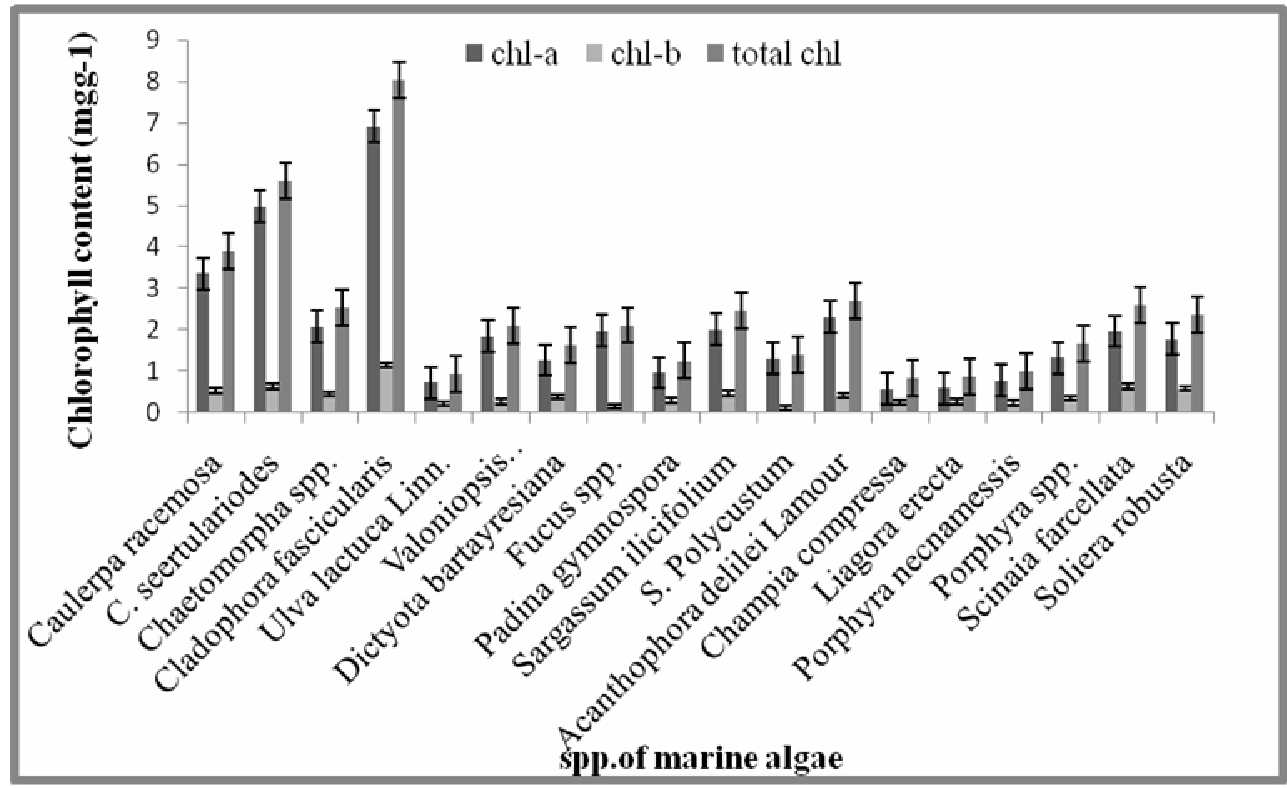

Figure 2. Shows pigment content- Chlorophyll $a, b$ and total chlorophyll in different marine macroalgal species.

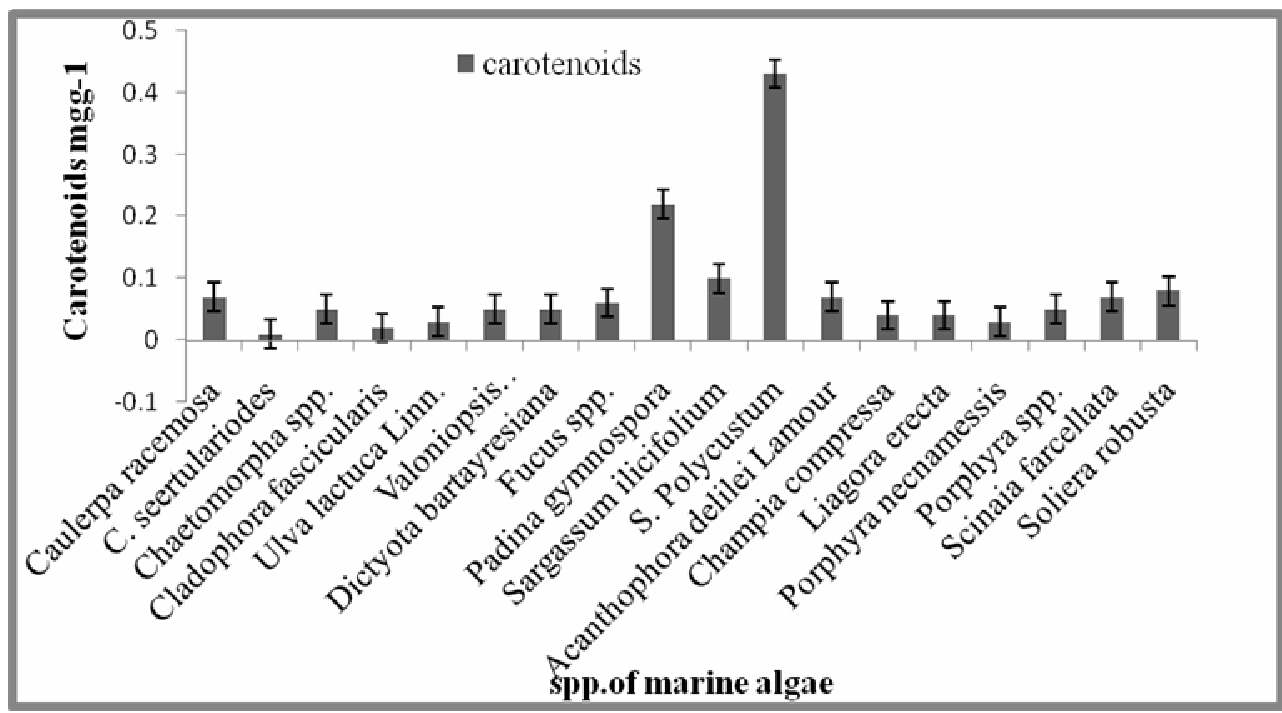

Figure 3. Shows Carotenoid content in different marine macroalgal species. 
N. Kumar J.I., R.N. Kumar, A. Bora, M. Kaur Amb and S. Chakraborthy / Our Nature

(2009) 7: 48-55

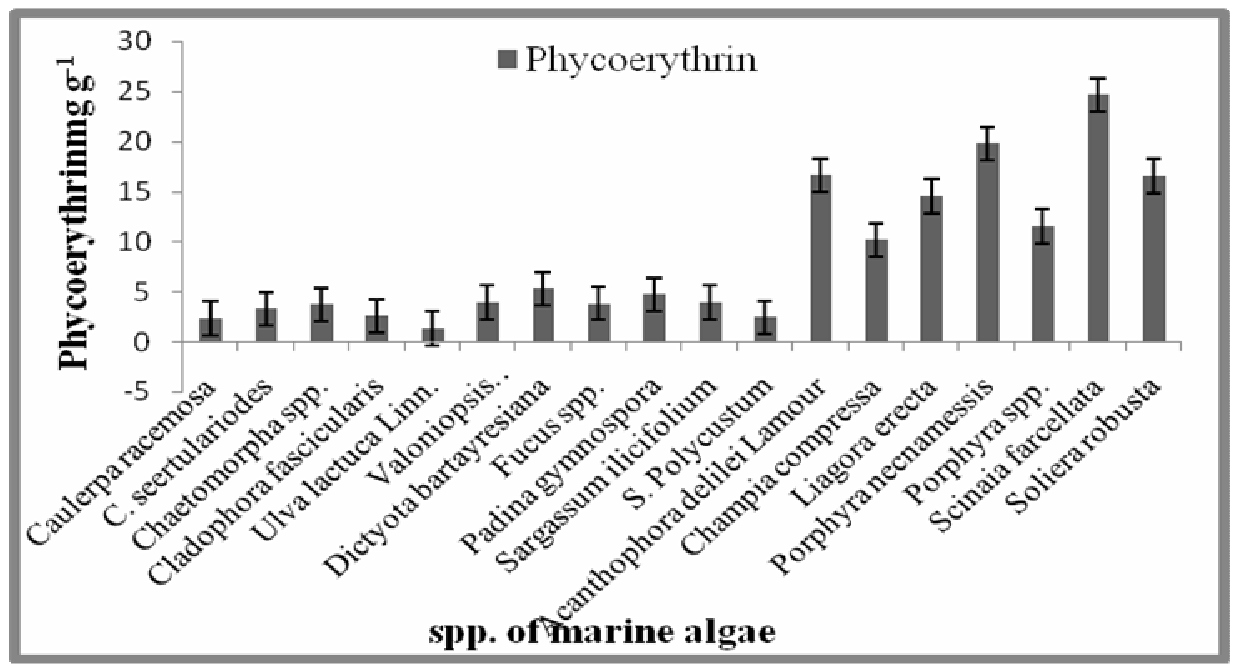

Figure 4. represents the phycoerythrin content in different species of marine macroalgae.

Table 2. Ratios of different species of marine algae

\begin{tabular}{llll}
\hline Pigments & Chl b/Chl a & Car/Chl a & Car/Chl b \\
\hline Chlorophyta & $\left(\mathrm{mg} \mathrm{g}^{-1}\right)$ & $\left(\mathrm{mg} \mathrm{g}^{-1}\right)$ & $\left(\mathrm{mg} \mathrm{g}^{-1}\right)$ \\
Caulerpa. Racemosa & 0.15 & 0.02 & 0.13 \\
C. seertulariodes & 0.12 & 0.002 & 0.02 \\
Chaetomorpha. spp. & 0.21 & 0.02 & 0.12 \\
Cladophora. Fascicularis & 0.16 & 0.003 & 0.02 \\
Ulva. lactuca Linn. & 0.28 & 0.04 & 0.15 \\
Valoniopsis. pachynema(martens)Boergs & 0.14 & 0.027 & 0.20 \\
\hline Phaeophyta & & & \\
Dictyota. Bartayresiana & 0.30 & 0.04 & 0.13 \\
Fucus. spp. & 0.07 & 0.03 & 0.06 \\
Padina. Gymnospora & 0.30 & 0.23 & 0.75 \\
Sargassum. Ilicifolium & 0.23 & 0.05 & 0.21 \\
S. Polycustum & 0.08 & 0.33 & 0.42 \\
\hline Rhodophyta & & & \\
Acanthophora. delilei Lamour & 0.17 & 0.03 & 0.18 \\
Champia. Compressa & 0.41 & 0.07 & 0.16 \\
Liagora. Erecta & 0.44 & 0.07 & 0.15 \\
Porphyra. Necnamessis & 0.29 & 0.04 & 0.13 \\
Porphyra. spp. & 0.26 & 0.04 & 0.14 \\
Scinaia. Farcellata & 0.32 & 0.03 & 0.12 \\
Soliera. Robusta & 0.33 & 0.04 & 0.14 \\
\hline
\end{tabular}


in different species of all the three groups can be written as: Rhodophyta > Phaeophyta $>$ Chlorophyta. Likewise, greater Car/Chl $a$ ratio was observed in $S$. polycustum $(0.33$ $\left.\mathrm{mg} \mathrm{g}^{-1} \quad \mathrm{FW}\right)$ followed by Padina gymnospora ( $\left.0.23 \mathrm{mg} \mathrm{g}^{-1} \mathrm{FW}\right)$. The least ratio was noted in $C$. seertulariodes $(0.002$ mg g ${ }^{-1}$ FW). In Chlorophyta, Phaeophyta and Rhodophyta the ratio ranged from 0.002 to $0.04 \mathrm{mg} \mathrm{g}^{-1} \mathrm{FW}, 0.03$ to $0.33 \mathrm{mg} \mathrm{g}^{-1} \mathrm{FW}$ and 0.03 to $0.07 \mathrm{mg} \mathrm{g}^{-1} \mathrm{FW}$ respectively. The Car/Chl $a$ ratio present in members of the three groups can be summarized as: Phaeophyta $>$ Rhodophyta $>$ Chlorophyta. On the other hand, highest $\mathrm{Car} / \mathrm{Chl} b$ ratio was noted in $P$. gymnospora $\left(0.75 \mathrm{mg} \mathrm{g}^{-1} \mathrm{FW}\right)$ followed by $S$. polycustum $\left(0.42 \mathrm{mg} \mathrm{g}^{-1}\right.$ FW). The lowest ratio was recorded in $C$. seertulariodes $\left(0.02 \quad \mathrm{mg}^{-1} \quad \mathrm{FW}\right)$. The $\mathrm{Car} / \mathrm{Chl} b$ ratio ranged from 0.02 to $0.20 \mathrm{mg}$ $\mathrm{g}^{-1} \mathrm{FW}, 0.06$ to $0.75 \mathrm{mg} \mathrm{g}^{-1} \mathrm{FW}$ and 0.12 to $0.18 \mathrm{mg} \mathrm{g}^{-1} \mathrm{FW}$ in Chlorophyta, Phaeophyta and Rhodophyta groups respectively. The $\mathrm{Car} / \mathrm{Chl} b$ ratio recorded in different species of all the three groups can be written as: Phaeophyta $>$ Rhodophyta $>$ Chlorophyta.

Similar findings and trends were also reported by Dere et al. (2003) who estimated the ratios of $\mathrm{Chl} a / \mathrm{Chl} b, \mathrm{Car} / \mathrm{Chl}$ $a$ and $\mathrm{Car} / \mathrm{Chl} b$ in marine macroalgae.

Among all the three groups, highest carotenoids were reported in $S$. polycustum $\left(0.43 \quad \mathrm{mg} \mathrm{g}^{-1} \quad \mathrm{FW}\right)$ followed by $P$. gymnospora $\left(0.22 \quad \mathrm{mg} \mathrm{g}^{-1} \mathrm{FW}\right)$, both belonging to the Phaeophyta group while the lowest carotenoid content was observed in C. seertulariodes $\left(0.01 \mathrm{mg} \mathrm{g}^{-1} \mathrm{FW}\right)$ belonging to the Chlorophyta group. Similar observations were also made by Fritsch (1971) who stated that there is high carotene content in brown algae. The carotenoid in species of Chlorophyta, Phaeophyta and Rhodophyta ranged from 0.01 to $0.07 \mathrm{mg} \mathrm{g}^{-1}$ FW 0.05 to $0.43 \mathrm{mg} \mathrm{g}^{-1} \mathrm{FW}$ and 0.03 to 0.08 $\mathrm{mg} \mathrm{g}^{-1}$ FW respectively. Accordingly, the order of the carotenoid content recorded in different species of the groups can be enlisted as: Phaeophyta > Rhodophyta > Chlorophyta. The results were found to be in confirmation with those by Chakraborty and Santra (2008).

Phycoerythrin content with respect to different marine algae is depicted in Figure 4. Correspondingly, the highest Phycoerythrin (PE) content was recorded in Scinaia farcellata (24.64 $\mathrm{mg} \mathrm{g}^{-1} \mathrm{FW}$ ) followed by Porphyra necnamessis (19.78 $\mathrm{mg} \mathrm{g}^{-1} \mathrm{FW}$ ). The lowest value was noted in Ulva lactuca Linn. (1.38 $\left.\mathrm{mg} \mathrm{g}^{-1} \mathrm{FW}\right)$. Phycoerythrin content was found to vary from 1.38 to $3.93 \mathrm{mg} \mathrm{g}^{-1}$ FW in Chlorophyta while in Phaeophyta phycoerythrin ranged from 2.46 to $5.31 \mathrm{mg} \mathrm{g}^{-1}$ FW. Phycoerythrin content in Rhodophyta fluctuated from 10.20 to $24.64 \mathrm{mg} \mathrm{g}^{-1} \mathrm{FW}$. The order of Phycoerythrin content registered in the members of the different groups can be arranged as Rhodophyta > Phaeophyta > Chlorophyta. The results are well corroborated with the findings of Gomez et al. (2004).

\section{Conclusion}

The present study reveals high pigment content in studied marine macroalgal species and the fact that their concentrations vary with different groups. Chlorophyll (Chl $a, b$ and total) content shot up in species of 
N. Kumar J.I., R.N. Kumar, A. Bora, M. Kaur Amb and S. Chakraborthy / Our Nature

(2009) 7: 48-55

Chlorophyta followed by Phaeophyta and Rhodophyta. Moreover, ratio such as $\mathrm{Chl}$ $b / \mathrm{Chl} a$ was highest in members of Rhodophyta followed by Phaeophyta and finally Chlorophyta. Likewise, Car/Chl $a$ ratio was estimated high in the species of Phaeophyta, while the least was noted in Chlorophyta. Car/Chl $b$ ratio also exhibited a similar order as that of $\mathrm{Car} / \mathrm{Chl} a$. Besides, Carotenoid content was recorded greater in the members of Phaeophyta than Rhodophyta and Chlorophyta. In contrast to chlorophyll and carotenoid, phycoerythrin content was found highest in the species of Rhodophyta.

\section{Acknowledgement}

Authors are thankful to UGC, New Delhi, India for providing financial support.

\section{References}

Anantharaman, P. 2002. Manual on identification of marine algae. All India Co-ordinated Project on Survey and Inventorization of Coastal and Marine Biodiversity (East Coast). 102 p.

Bennett, A. and L. Bogorad 1973. Complementary chromatic adaptation in a filamentous blue-green alga. The J. of Cell Biol. 58: 419-435.

Chakraborty, S. and S.C. Santra 2008. Biochemical composition of eight benthic algae collected from Sunderban. Indian J. of Marine Sciences 37(3): 329-332.

Dere, Ş., N. Dalkiran, D. Karacaoglu, G. Yildiz and E. Dere 2003. The determination of total protein, total soluble carbohydrate and pigment contents of some macroalgae collected from Gemlik-Karacaali (Bursa) and Erdek-Ormanli (Balikesir) in the Sea of Marmara, Turkey. Oceanologia.45 (3): 453-471.

Ekpenyong, E. 2000. Algal biomass and pigment diversity in typical tropical fish ponds. Tropical Ecology 41(1): 89-94.
Francisco, J.L.G., J. Aguilera and C. Jimenez 2006. The response of nutrient assimilation and biochemical composition of Arctic sea-weeds to a nutrient input in summer. J. Exp. Botany. Doi: 10.1093/jxb/er1029.

Fritsch, F.E. 1971. The structure and reproduction of the algae, Vol I, Cambridge Univ. Press, Cambridge. $791 \mathrm{p}$.

Gomez, I., F. Lopez-Figueroa, N. Ulloa, V. Morales, C. Lovengreen, P. Huovinen and S. Hess 2004. Patterns of photosynthesis in 18 species of intertidal macroalgae from southern Chile. Mar. Ecol. Prog. Ser. 270: 103-116.

Jeffrey, S.W. and G.F. Humphrey 1975. New spectrophotometric equations for determining chlorophylls a, b, c1 and c2 in higher plants, algae and natural populations. Biochem. Physio. Pflanzen 167: 191-194.

Kannan, L. and T. Thangaradjou 1998. Seaweeds and seagrasses of Porto Novo. $46 \mathrm{p}$.

Lewin, R.A. 1974. Biochemical taxonomy. In Algal physiology and biochemistry (Ed. W.D.P. Stewart). Blackwell Scientific Publications, Oxford and London. 989 p.

McClanahan, T.R., B.A. Cokos and E. Sala 2002. Algal growth and species composition under experimental control of herbivovy, phosphorous and coral abundance in Glovers Reef, Belize. Mar. Poll. Bull. 44: 441-551.

Parsons, T.R. and J.D. Strickland 1963. Discussion of spectrophotometric determination of marine plant pigments with revised equations for ascertaining chlorophylls and carotenoids. J. Mar. Res. 21: 155163.

Thakur, M.C., C.R.K. Reddy and B. Jha 2008. Seasonal variation in biomass and species composition of seaweeds stranded along Port Okha, northwest coast of India. J. Earth Syst. Sci. 117(3): 211-218.

University of California. 2009. Photosynthetic pigments. http://www.ucmp.berkeley.edu/glossary/ gloss3/pigments.html

Wilson, S. 2002. Nutritional value of detritus and algae in blenny territories on the Great Barrier Reef. J. Exp. Mar. Biol. Ecol. 271: 155-169. 